\title{
Assessment Practices and Challenges of Training and Development at the Ethiopian Textile Industry Development Institute(ETIDI)
}

\author{
Birhanu Woldeyohannes $^{1} \quad$ Tesfaye Alebachew ${ }^{2}$ \\ 1.Research fellow in Ethiopian Civil service University, department of Development Economics, Addis Ababa \\ Ethiopia \\ 2. change management and good goverance team leader in Addis Ababa Transport Bureau, Addis Ababa, \\ Ethiopia
}

\begin{abstract}
Employees are considered as the key determinants of the success of an organization that shall have different training and development so as to cope up with the fast-changing business world. Training and development programs are essential for every organization for its long term planning that requires careful preparation if they are to be successful and help to achieve its objectives in time and enhance the knowledge, skills, and competencies of its workforce. The overall objective of this study is to assess the practices and challenges of training and development at the Ethiopian Textile Industry Development Institute(ETIDI). The study adopted a mixed approach and used both primary and secondary data sources. The primary data collected from ETIDI through selfadministered questionnaire for 116 selected operating employees and middle-level managers using a purposive sampling method to make sure that they have gone through the training program or understand the training and development program in the institute and semi-structured interview question employed for top managers(directors and deputy directors and training coordinator) through interview. The collected data were analyzed by using statistical tools (SPSS-Version 22). Both descriptive and inferential statistics were used for the data analysis. The descriptive statistics such as frequency and percent were used for describing the demographic characteristics of respondents and the dependent and independent variables. Qualitative data obtained through interviews were analyzed using content analysis. Inferential statistics like Pearson correlation coefficient(r) and multiple linear regression were used to determine if there is a relationship existed between independent and dependent variables. The study shows that $62.5 \%$ of the variation in the dependent variable was explained by independent variables. The findings also indicated that the relationship between the dependent variable was positively correlated and claimed to be a statistically significant relationship with the independent variables. The findings of the study indicated that there is no series of attention to allocate enough time, sufficient budget and resource for the training and development; in ETIDI there is no SMART manual and instrument of need assessment; training and development need assessment is not prepared by considering the need of prospective trainees; the organized training by the Institute is for the sake of refreshment or to collect allowance with less attention to the outcome of the training; training and development objectives are not set in advance; training and development program of the organization is not designed in line with the actual job to be performed and training and development program not followed by a reward. Hence, the researcher recommended that the management of the institute, the board, and other stakeholders should define an appropriate training and development policy and programs that bring or capacitate the organization as well as the employee, Staff in the institute should be helped to grow into more responsibility by systematic training and development rather than consider it training as means to make themselves free from staff routine and receive allowance without considering the objective and benefits of training for themselves and for their institute so that they will be confident enough to carry out the responsibility of the job and the management of the institute, the board, and other concerned bodies should come up with training and development practices and policies for their ETIDI because they are the strategic link between the institute's vision and its day-to-day operations.
\end{abstract}

Keywords: SMART manual, training and development, reward

DOI: $10.7176 / \mathrm{JAAS} / 68-02$

Publication date:September $30^{\text {th }} 2020$

\section{Background of the Study}

Organization as a system used different types of resources, including physical, financial, material and human resources. Among these resources, human resources is the most critical asset of a business and it is the engine that helps the organization to achieve its missions and meet its goals. The success of any organization mainly depends on which include the knowledge, skill, aptitude, commitment, wisdom and attitude of the organization's human resource. To this practice, building the human resource capacity for the organization through training and development is fundamental. Thus, an organization has an obligation to invest in human resource capacity building to accomplish its purpose. The more endeavor is taken to augment the management competency it will bring higher 
organizational performance. Hence, the provision of training and development are the main measures to bring improved organizational performance through the systematical development of work-related knowledge, skill and expertise of the organization human resource.

The level of the country in the area of its economic, political and legal, social and technological development depends mainly upon the attention given to carry out capacity building endeavors for its citizen. Consequently, countries vary from one to the other by their level of the human capacity building provided for its human resource involved in various areas of development programs. Based on these fact countries of the world are categories as developed, developing and underdeveloped. In the same manner, what distinguishes a successful company from unsuccessful ones is the quality of its manpower. The survival of any organization depends on the quality of human resources. Without properly educated or trained human resources, talking about development is worthless. Thus organizations should develop and train their employees in order to increase productivity and its efficiency. In Private, governmental, or non-governmental organizations, human resource capacity building is unquestionably very important. Training and development play a key role in equipping the employees with the necessary skills, knowledge, and attitude. (Noe, Hollenbeck \& Wright, 2011).

Training and development enhance the organization's strategic goals and objectives including organizational culture and ensuring health and safety. Regarding the benefits of training and development for the organization, Anderson(2000) states the following: Training and development are best seen as an incentive that can enhance organizational commitment, team effort, customer relations, etc. However, on the purely individual level without encouraging upon an organizational impact, innate incentives can be realized through training (Anderson, 2000:22). cited Mengestu. June 2014 ).

Moreover, training and development programs are essential for every organization for its long term planning that requires careful preparation if they are to be successful and help to achieve its objectives in time and enhance the knowledge, skills and competencies of its workforce. Training not only develops the capabilities of the employee but sharpen their thinking ability and creativity in order to take better decision in time and in a more productive manner (David, 2006).

Employees are considered as the key determinants of the success of an organization that shall have different trainings and development so as to cope up with the fast-changing business world. As pointed out by Kossen.S (1991) skill and knowledge can easily become out of date in the same way as machines or technology.

Every government and non-government organization is required to develop the capacity and potential of all its employees irrespective of their status by providing training and development. The fundamental aim of training and development is to enhance resource capability in accordance with the belief that the human capital of an organization is a major source of competitive advantage (Wright and Geroy, 2001).

Technological developments and organizational change have gradually led a number of managers to realize that success relies on the skills and abilities of their employees, and this means considerable and continuous investment in training and development (Beardwell, Holden and Claydon, 2004). To be persistent and recognize this national target, provision of adequate funds for the renovation of the exist $\neg$ ing textile mechanized sector; and the government has been determined to create an investor-friendly business setting to attract domestic and foreign direct investment with Competitive power rates and availability of inexpensive and trainable labor force.

Accordingly, the Ethiopian Textile Industry Development Institute (ETIDI) is established by the Council Ministries Regulation no.180/2010 article to Prepare, disseminate and coordinate those project profiles and to expand investment in the textile and apparel industries; for those local and foreign investors desiring to engage in the sector by accelerating the Ethiopian cotton and textile development industry sector to be competitive in the global market and striving by providing sustainable investment opportunities, standard preparation, consultancy service, input facilitation and support, quality testing, human re $\neg$ source development, study, research, laboratory and marketing support services with a vision of aspiring to be a preliminary sector in Africa that enables the Ethiopian textile industry competitive in the global market and aligning with the spearhead countries in 2025.

Thus, the purpose of the study is to assess the practice and challenges of training and development on organizational performance using the Ethiopian Textile Industry Development Institute as a case study and provide suggestions and recommendations based on the study findings to the administration as to how it can make the best use of training development programs to make their employees perform well on their job.

\section{Statement of the Problem}

The effectiveness and success of an organization are determined by the people who work within the organization. The ability of workers is to perform their duties and make their meaningful contributions to the success of the organizational goals. The goal of any organization is increasing productivity and improved quality of service. For the success of the above accomplishment and objectives is needed to acquire the relevant skills, knowledge, and attitude. Skill and knowledge can be obsolete then it must be strategically and consistently kept up to date if the organization is to survive and develop. Then continuous training and development are very crucial for the success of organization viability because it motivates, improves employee morale and human relation, increases the skill 
of employees and upgrades the ability of managers to perform their task. According to their need different factors that challenge the training and development practices of the organization. Among the factors that hindered the practice of training and development, economic, social, technological, and political and legal situation. It has been known that some governmental, private, and international organizations fail to recognize the importance of training to increase their employees' productivity and when the economy slows or when profits decline, these organizations first seek cuts in their training budgets. This will leads to high job turnover then increase the cost to hire new employees which lower down the organization's performance as well as profitability and customer satisfaction. In Ethiopian Textile Industry Development Institute (ETIDI), there are many challenges in line with training and development of human resource which include absence of proper need assessment and identification of gap in knowledge, attitude and skills of human resource; proper consideration to ensure that the training and development of the organization is inclusive by sex, position, and profession, staff and line departments; proper attention providing for training and development and allocation of sufficient/adequate budget to execute the purpose; adequate attentions to ensure that the training and development implementation strategy and method are used for selection of the trainees to fill the identified need gap; available system or mechanism utilized by the organization which give opportunity for the workers' self-development; provision of training is based on changing environment and technology and progressive; identification of competitive training and development centers provide training for the selected trainees; adequate provision of awareness for the trainees before staring training program which will able them to attend properly and obtain adequate knowledge and skill to cope with their duties; the training and development provided by the training institute about the general principles but does not consider the problem of the organization; there is proper evaluation of the outcome of the training and development; there is wellverified method of training and the need assessment; the training and development was carried out with aboard countries but the intention is not to bring change on the organization but it has an intention to collect some about of money for personal again (Ethiopian textile development institute un published report document, 2017).

Some of the local studies have the following finding. Anasimos Alye (2016) shows that there is no statistically significant difference and there is also a gap between the ideal training and development practice and the actual practices employed by the banks studied. Amsalu Tegegne (2017) showed that there is a positive and significant relationship between training and employee performance in the context of the Gulelle Sub-city administration sector's and training and development was found to be a positive predictor of employee performance, administrators should engage in increasing the qualities and quantities of the training program so as to increase their employee's performance. Regarding the frequency of training provided, many respondents, i.e., 93 out of 282 respondents avowed that they took training for one or two times. This may retard the effectiveness and motivation of employees of the organization. Regarding the methods implemented to deliver training, the company mostly used a trainer centered (lecture) in which 67 percent (189 out of 282 respondents) affirmed that they took training through lectures.

Assefa Gidey (2016) pointed out that there is a positive and significant relationship between training and employee performance in the context of Commercial Bank of Ethiopia training and development was found to be a positive predictor of employee performance, administrators should engage in increasing the qualities and quantities of the training program so as to increase their employee's performance. Bitew Amare (2016) found out that the organization has no defined training and development policy and the practices of training and development are not conducted based on policy. The training needs assessment was found not made properly. The organization has no realistic training and development objectives and roles. The organization training and development plan are not well communicated to all employees. Training and development programs are not evaluated and designed compatible with the actual job to be performed and do not able to improve the skills, knowledge, and attitude of employees which can increase performance on the job. This study attempted to investigate the practice and challenges of training and development on organizational performance using the Ethiopian Textile Industry Development Institute

\section{Objectives of the study General Objectives}

The general objective of this study is to assess the practices and challenges of training and development at the Ethiopian Textile Industry Development Institute.

\section{Specific Objectives}

This study intended to address the following objectives:

- To assess training and development policies directives and resources in the Ethiopian Textile Industry Development Institute.

- $\quad$ To investigate the practice of training and development need assessment in the Ethiopian Textile Industry Development Institute.

- To assess the training and development plans objectives and roles in the Ethiopian Textile Industry 
Development Institute.

- To identify the method of training delivery and development practices in the Ethiopian Textile Industry Development Institute.

- To investigate the training and development evaluation practice in the Ethiopian Textile Industry Development Institute.

- To examine problems or challenges of training and development in the Ethiopian Textile Industry Development Institute.

\section{Significance of the Study}

The study deals with training and development practices and challenges to identify the concerned organization's performance (ETIDI). At the end of the research, the researcher will recommend some possible solutions to overcome problems of training and development. The findings result of this research work is expected to provide the following significant advantages. Suggest possible solutions for the identified challenges that need vital improvement for decision-makers .serve as input for re-examining how much they were efficient and effective from the previous training practice that employed by the organization towards improving its performance by taking corrective actions for future; and It serves as an opportunity to gain possible knowledge, skill, and attitude in the area and may be used as a background secondary source of data for those who want to conduct similar research.

\section{REVIEW OF THE RELATED LITERATURE}

\section{Theoretical Foundation}

As the literature suggests, the nature of the training in the public sector has changed over recent decades. Traditionally, training was considered to be job-focused, limited to the technical skills and abilities needed by public employees to perform specific tasks. As such, it was differentiated from education, which was considered to be broader in scope, more oriented toward a range of future jobs, and generally provided by institutions of higher learning. Traditionally, individuals obtained their education first and subsequently received training in the work environment. Recently, the distinction between training, education, and development have become blurred (Van Wart, Cayer, and Cook, 1993 as cited in Amadi, 2014). As public organizations find themselves needing to help employees learn about new technologies and skills, training, in many instances, has begun to look like what has traditionally been called education.

According to De Sario et.al. (1994 ibid), training-refers to learning experiences designed to enhance the shortterm and/or long-term job performance of individual employeesll. In this respect, training is viewed as part of an on-going developmental process. Training needs to be linked with the organizational mission (Fletcher, 1985; Fischer, 1989; Latham, 1988; Miller, 1989 ibid). So, when local governments plan their training activities, they need to provide the link with the organizational mission and local budget and implementation.

Some authors suggest considering training as investment decisions Eurich, (1985 as cited in Amadi,2014), and they should be made after careful consideration. It is usually advised that training activities should be examined from the perspective of their ability to influence individual job performance, rather than isolated experiences that may or may not contribute to the organization's success. McGehee and Thayer (1961) are usually regarded as the authors of the first textbook on training in organizations. They suggested a three-fold approach to determine the types of training and development experiences that should be implemented, including organizational analyses, task analyses, and person analyses. Accordingly, organizational analyses focus on the organization's ability to support training. Task analyses focus on the knowledge, skills, abilities, and other personal characteristics required to perform the agency 's task. Person analyses focus on the needs of the individual, identifying personal characteristics possessed by the particular individual. There are two basic questions that must be addressed in the design of training activities. The first is the question of how a given course should be delivered. Who should participate? Where the course should be held? What types of learning tools should be used in the program? A second question is the creation of a learning experience that improves the transfer of knowledge. It is not enough for the trainees to learn; they must be able and willing to seek new abilities on their job. From the field of adult education, it is well known that adults are learning differently than children. First of all, adults have to know why they should learn something.

\section{The Concept of Training and Development}

Noe, (2001) says that organizations that embrace training and development practices are able to retain their customers, suppliers, employees, shareholders, and other stakeholders in the long run as they are deemed more trustworthy and better custodians of the interests of the various stakeholders. This translates into better financial performance for the business. Myles (2002), states that a company that seeks to train and develop its employees well and reward them for their performance has its employees, in turn, are motivated and thus are more likely to engage in their work hence improving their performance and loyalty to their company. These same employees being the point of contact with customers will provide better service, leading to more repeat business and more 
referrals from satisfied customers. The increase in sales through repeat business and referrals will translate into an increase in business profits thus improving shareholders 'investment. The shareholders are therefore benefiting from the increased returns on their investment and may choose to increase their investment into the business.

Wiesenberger and others (1986) defined the training as giving new and different skills to the employees for performing their jobs. Armstrong (2006) suggests that" training can refer to the practice of equipping employees with skills, knowledge, and abilities, with the aim of building organizational capabilities and increasing organizational performance".

Development is a broad ongoing multi-faceted set of activities (training activities among them) aimed at bringing someone or an organization up to another threshold of performance, often to perform some job or a new role in the future (McNamara, 2008 as cited in Amsalu,2017).

According to Neelam et al., (2014, ibid) Training and development are defined as the planned learning experiences that teach employees how to perform current and future jobs. These two processes, Training, and Development, are often closely connected. Training can be used as a proactive means for developing skills and expertise to prevent problems from arising and can also be an effective tool in addressing any skills or performance gaps among staff. Development can be used to create solutions to workplace issues, before they become a concern or after they become identifiable problems. Training is a systematic restructuring of behavior, attitude, and skills through learning- education, instruction, and planned experience. The cardinal purpose of training is to assist the organization achieves its short and long term objectives by adding value to its human capital. Training and development are not undertaken for the sake of training, but rather are designed to achieve some needs.

In the modern workplace, these efforts have taken on a broad range of applications from instruction in highly specific job skills to long-term professional development. In recent years, training and development have emerged as a formal business function, an integral element of strategy, and a recognized profession with distinct theories and methodologies. More and more companies of all sizes have embraced "continue all earning" and other aspects of training and development as a means of promoting employee growth and acquiring a highly skilled workforce. In fact, the quality of employees and the continual improvement of their skills and productivity through training are now widely recognized as vital factors in ensuring the long-term success and profitability of businesses and in addition create a corporate culture that supports continual learning (Mamoria 1995). Therefore, Training and development in today's employment setting are far more appropriate than training alone since human resources can exert their full potentials only when the learning process goes beyond the simple routine (Pallavi, et al.2013).

As cited in Abeeha and Bariha, (2012) while considering a training process its essential to explore who is taking part in training, the style and design of training and all about the main objectivity of the training being achieved or not (Choo\&Bowley, 2007). Stephen \&Bowley (2007) focus on the outcome of capital invested in training processes that further raise the efficiency of the employees and the organization. The quality of a trainer is also a key element that affects training productivity. The course design for the training and the trainer selection speaks about the success and the failure of the training itself.

Effective training and development programs aimed at improving the employees' performance. Training refers to bridging the gap between the current performance and the standard desired performance. Training could be given through different methods such as coaching and mentoring, peer cooperation and participation by the subordinates. This teamwork enables employees to actively participate in the job and produces better performance, hence improving organizational performance.

Effective training is beneficial for the firm in a variety of ways, such as it plays a vital role in building and maintaining capabilities, both on an individual and organizational level, and thus participates in the process of organizational change (Valle, Martin, Romero, \& Dollan, 2000, pp. 283-97).

Different organizational strategies call for tailor-made HR strategies. Staffing, training and development, motivation and maintenance all must emphasize factors that support the strategy through human capital related areas such as building, developing, maintaining a productive and talented workforce(Dacenzo \& Robbins, 2010).

One major area of the Human Resource Management function of particular relevance to the effective use of human resources in training and development.

People these days would argue against the importance of training as a major influence on the success of an organization. Employees are a crucial, but an expensive resource.

Training and development functions are activities in HRM concerned with assisting employees to develop up-to-date skills, knowledge, and abilities (Dacenzo \& Robbins, 2010, p. 36).

In today's demanding and rapidly changing business environment, more and more companies are viewing employees upon the talent upon which the organization's success is dependent. Organizations and their employees must constantly expand their competencies to meet customer needs and operate globally(Steen, Noe, Hollenbeck, Barry, \& Write, 2009, p. 207).

Human Resource management writers identify the difference between human resource development and training.

According to Steen et.al.(Steen, Noe, Hollenbeck, Barry, \& Write, 2009, p. 207), training consists of an 
organization's planned effort to help employees acquire job-related competencies with a goal of applying these on the job whereas employee development is the combination of formal education, job experience, relationships, and assessment of personalities and competencies to help employees prepare for the future of their career.

\section{The Importance of Training and Development}

As quoted by Kuan Chongtzu, a great man of China:" If you wish to plan for a year: sow seeds. If you wish to plan for ten years; plant trees. If you wish to plan for a lifetime; develop man". This statement evidentially makes mention of the importance of Training and Development in organizations. Training and development activities are a continuing process beginning with the first day on the job, building skills for high performance, and high morale (Dacenzo\& Robbins 2010).

An effective training program actually teaches what it designed to teach, and it teaches skills and behavior that will help the organization achieve its goals (Steen, Noe, Hollenbeck, Barry, \& Write, 2009, p. 209).

It involves the use of formal processes to impart knowledge and help people to acquire the skills necessary for them to perform their jobs satisfactorily (Armstrong, 2006, p. 575). Training can help in the creation of a more productive, skilled, and adaptable workforce (Holbeche, 2009, p. 146). If executed correctly, the effects of training on employee performance can often encourage growth within the worker and the employee itself (Katcher \& Snyder, 2003).

The training program prepares employees for future positions in the organization, enable the organization to respond to change, reduce turnover, enhance worker safety, improve customer satisfaction and product design, and meet many other goals (Steen, Noe, Hollenbeck, Barry, \& Write, 2009, p. 208).

Employee development is something that most people imagine as intrusive all-day group training sessions. Unfortunately, this dreaded approach to employee development is just the opposite of how employee development should occur and feel to employees. Employee development can manifest itself in many forms of training, evaluation, educational programs, and even feedback. If executed correctly, the effects of training on employee performance can often encourage growth within the worker and the organization itself (Katcher \& Snyder, 2003).

Employees who receive training in line with their individual or organizational goals will become more efficient in what they do. To be prepared for rapidly changing conditions and normal attrition, each organization must provide training for its employees (Scannell \& Les, Human Resource Development: The new trainer's guide, 2000, p. 2).

Attaran and Nguyen suggest that training in problem-solving, communications, and time management is important (Attaran \& Nguyen, 2000). Applebaum et al. (1999) recommend training in conflict management (Derek, Laura, \& Stephen, 2005, p. 295). Employee development implies learning that is not necessarily related to the employee's current job (Steen et al, 2009, p. 230). According to them it, instead, prepares employees for other positions in the organization and increases their ability to move into jobs that may not yet exist.

The approaches to employee development fall into four broad categories: Formal education, assessment, job experience, and interpersonal relationship (Steen, Noe, Hollenbeck, Barry, \& Write, 2009, p. 231).

Employee Development is also attached with the career development and management of employees Career management is the process through which organizations select, assess, assign and develop employees to provide a pool of qualified people to meet future needs (Jackson \& Rowley, 2011, p. 12). The focus of career development is to provide the necessary information and assessment in helping employees realize their career goals. However, career development is the responsibility of the individual, not the organization (Decenzo \& Robbins, 2010, p. 36)

In spite of the innumerable reasons and benefits derived from training, in most cases, training and development programs fail. This is regardless of whether the course is attended in the best universities or delivered by the most prominent trainer. This tells us that there are factors those affecting training. Feedback is a very important condition for the successful acquisition of skills. Training can be done mentally, where the employees go over the events in their heads in order to be properly prepared.

It is important that information is given correctly in the early stages of learning. This is so because if errors are not picked up early, the employee will be greatly disadvantaged when someone spots them later. Indeed, if the employees have been applying such faulty skills for years, it may mean that they are never fixed. The role of practice in the business of skills acquisition is very important when one thinks how much time employees spend perfecting the skills involved in their tasks. The main purpose of job training is to give employees the knowledge and skills they need to perform effectively in their fields of expertise.

\section{Training need assessment}

Training needs assessment, TNA for short, is the process of collecting information about an expressed or implied organizational need that could be met by conducting training. The need can be a performance that does not meet the current standard. It means that there is a prescribed or best way of doing a task and that variance from it is creating a problem. The TNA process helps the trainer and the person requesting the training to specify the training need or performance deficiency. 
As employee development is futuristic in nature, the training need assessment can also be important to identify the required training to develop employees for future assignments.

\section{Typical training methods}

Rhernebergen and Wognum (2002) have described core development as a process organization deliberately undertake in order to develop its employees to meet future challenges. Management also this process to develop a proper human resources development program that ensures employees are trained and their skills are upgraded as they go up the organization's ladder to occupy positions of higher responsibilities. Keissler (2002) argues that career development facilitates the organization's objective of showing a well-articulated growth-oriented yet flexible path to its employees. Information technology on the other hand has been hailed as a catalyst for human resources development. Powel (1997) investigated linkages between information technology and performance and observed that information technology alone cannot produce sustainable performance advantages in the organization but that firms had gained advantages, by using information technology to leverage performance.

Beardwell and Holden (1994), pinpoint that careful use of training methods can be a very cost-effective investment in the sense of using appropriate methods. Further, they state that, if an increase in the training methods is not appropriate, trainees may end up not benefiting from the exercise. Broadly, training programs are classified into on-the-job training and off-the-job training. On-the-job training - this is probably the most common approach to training and range from the selectively unsophisticated approach which involves verbal instructions or demonstrations of how to use tools and other equipment. According to Armstrong (1998), on-the-job training is useful in developing and practicing specific managerial, leadership, technical, manual and administrative skills needed by the organization to improve competitiveness. It has the advantage of actuality and immediate since the trainee works, learns and develops expertise at the same time. Jacob et al (1985) argue that on-the-job training focuses on the acquisition of skills within the work environment generally under normal working conditions.

Rothwell et al (1994) observed that on-the-job training has been used to develop employees and typically includes verbal and written instructions, demonstrations and observations and hands-on practice imitation. Generally, the on-the-job training includes the following types of training, orientation or induction training, apprenticeship, and refresher training. Off-the-job training - sometimes may be necessary to get away from the immediate work environment to a place where the frustration and hustle of work are eliminated. This enables the trainees to study theoretical information or be exposed to new and innovative ideas. This type of training takes place on special courses or in a training area or center that has been specifically equipped and staffed for training. They include lectures, training by management institutions, conferences, seminars, case studies, brainstorming. According to Lisk (1996), human resources training and development approaches can be viewed from two perspectives, the macro, and micro-practices. The micro identifies the degree to which internal career development systems facilitate organizational progression and personal development. It also addresses the extent to which organizations perceive a need for skill enhancement to equip employees with relevant skills for future work demand. These approaches include career development information technology, job rotation, job design, job enhancement, job enlargement, 360 degrees feedback, and on-the-job training. Decenzo and Robbins identified two major training methods (Armstrong, 2008, p. 192). They are on-the-job training and Off-the-job training.

\section{Evaluation of Training and Development Programs}

How to determine whether a training program is effective or not? One way is to measure the change in outputs in terms of costs, sales, production, employee turnover, or revenue. The HRM can compute the Return on Investment (ROI) by determining the benefit of the training and dividing it by training expenses (Decenzo, Robbins, \&Verhulst, 2010). According to Armstrong (2003), training and development programs should be monitored continually to ensure that plans are going according to budget. To ensure managerial results, training should be evaluated after each event. So evaluation must be objective and targeted as an important outcome; accomplished according to agreed evaluation; matched with organization philosophy, culture, and objective and should be reasonable.

\section{Data and Research Methodology Conceptual Model of the study}

Training and development are most effective in motivating and retaining high-quality human resources within the organization (Kate Hutchings, Cherrie J.Zhu, Brain K, Cooper, Yiming Zhang, and Sijun Shao, 2009). During the 1980s, Japanese management practices clearly revealed that business success based on high standards of performance was dependent on a highly trained and developed workforce (Brown and Read, 1984). It has been confirmed that organizations with more progressive people-oriented policies have excelled, leaving the competition behind. This mainly because when organizations invest in people in training, what they get in return is a higher skill and greater competence that helps improve morale and productivity (Sheeba Hamid, 2011). Many scholars have proved that effective training and development; which is an independent variable have practice and challenges which is the dependent variable. 
Figure 1: Dependent and independent variables Independent Variables

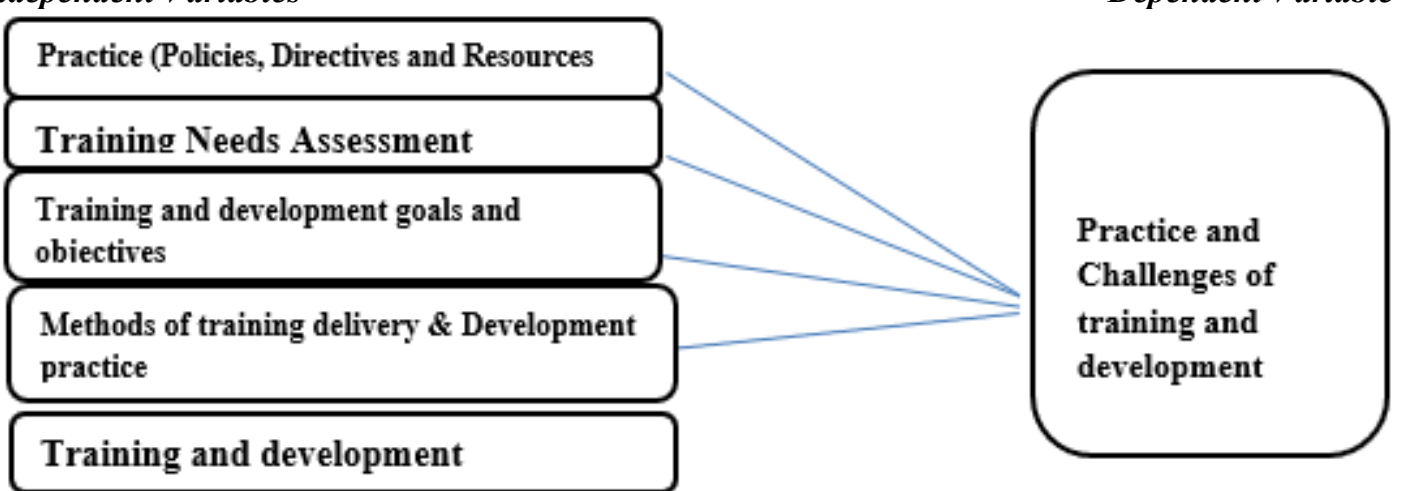

Source: Raja, Furguand Mohammed. (2011).

\section{Research Design}

Quantitative and qualitative research tools were used in order to produce a richer and more factual report. The mixed strategy enables to convert of quantitative and qualitative data in order to provide a comprehensive analysis of the research problem (Creswell, 2013 as cited by Abenet, 2016). Particularly, a descriptive survey design was employed since it is an appropriate method that enhances the research to assess the existing practices and challenges of Training and Development at the Ethiopian Textile Industry Development Institute. The researchers felt that the selected method is appropriate.

\section{Data source}

The major sources of primary information for the study were trainee employees, team leaders, middle-level managers, and higher officials of the institution. The documents in the institute which are related to training and development were assessed as a source of secondary data. The use of secondary data sources is mainly to crosscheck with the results of the primary data.

\section{Total population, Sampling Size, and Sampling Method}

The total population of the study comprises 280 employees of the Ethiopian Textile Industry Development Institute. The total population has been divided into four strata (top managers, middle-level managers, lower-level managers, and operating employees).To collect data through questionnaire from lower-level managers and operating employees we use a formula developed by (Yamane, 1967) as:

$$
n=\frac{\mathrm{N}}{1+\mathrm{N}(\mathrm{e}) 2}
$$

Where $\mathrm{n}=$ the desired sample size, $\mathrm{N}=$ Population size and $\mathrm{e}=$ level of precision

$$
n=\frac{270}{1+270(0.07) 2}=116
$$

Therefore the total sample size was 116 operating employees and team leaders. Of which 100 is allotted proportionally for operating employees, 10 allotted to top managers( 8 directors and 2 general deputy directors) and 6 alloted to middle-level managers and lower-level managers (team leaders). All the participants are selected using a purposive sampling method to make sure that they have gone through the training program or understand the training and development program in the institute. This method helps to include only those who provide relevant data for the current study.

\section{Data Collection method and instrument}

According to Ahmed (2014), a questionnaire is a powerful evaluation tool in behavioral sciences. If well designed, it can be a very reliable and veritable tool. In a questionnaire, respondents read the questions, interpret what is expected, and then write down the answers Kumar (2011). Having this advantage in mind; close-ended and openended questions were developed and distributed to students and teachers of target schools. The data was collected mainly by using a questionnaire which was consisting of both open- and close-ended items.

\section{Interview}

Interviews are a more personalized form of data collection method than questionnaires, and to obtain data for further clarity and credibility of the research are involving one-to-one. Semi-structured as questionnaire surveys the same research protocol interviews with selected respondents who were selected based on purposive sampling will be conducted by trained interviewers. The interview guideline was produced and a Semi-structured interview 
was used to conduct particularly for General and Deputy Directors.

\section{Methods of Data Analysis}

The quantitative data gathered from the respondents were analyzed by using a descriptive (frequency and percent) and inferential statistics (correlation and regression analysis) statistics. In addition to this, the qualitative data obtained through the interview was presented through narration.

\section{Result and discussion}

\section{Response rate}

A total of 116 questionnaires were distributed to the respondents of which 72 questionnaires were properly filled and returned back. The response rate in this case 62 percent which is higher than the acceptable level ( 30 percent) when the questionnaire was used in the study.

\section{Socio-Demographic Characteristics of Respondents}

\section{Position of Respondents}

Figure 2 illustrated the socio-demographic characteristics of respondents. The first socio-demographic characteristic is the position regarding the position of respondents $60(83.3 \%)$ of the respondents were operating employees while $12(16.7 \%)$ of the respondents were middle and lower managers(team leader). From the above information, it is possible to conclude that the majority of the respondents were employees.

\section{Figure 2: Distribution Position of Respondents}

\section{team Leaders $\quad$ Employees}

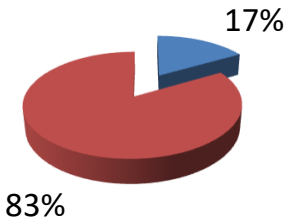

Source: own computation from field Survey

\section{Sex of respondents}

Figure 3 showed that the second socio-demographic characteristics was sex $56(77.8 \%)$ of the respondents were male while $16(22.2 \%)$ of the respondents were female. From the above information, it is possible to say that the majority of respondents were males. The dominant number of institute employee was male. This may be due to the case the industry is labor intensive.

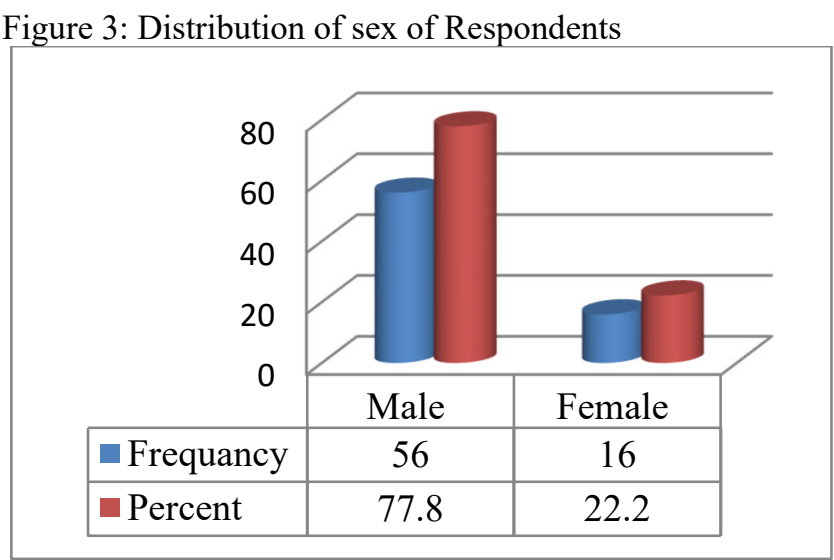

Source: own computation from field Survey

\section{Age of respondents}

As shown in figure 4 about one in two (45.8\%) of the respondents were in the age category of $31-40$ years . This closely followed by age category of $20-30$ years( $43.1 \%)$. 
Figure 4: Distribution of Age of Respondents

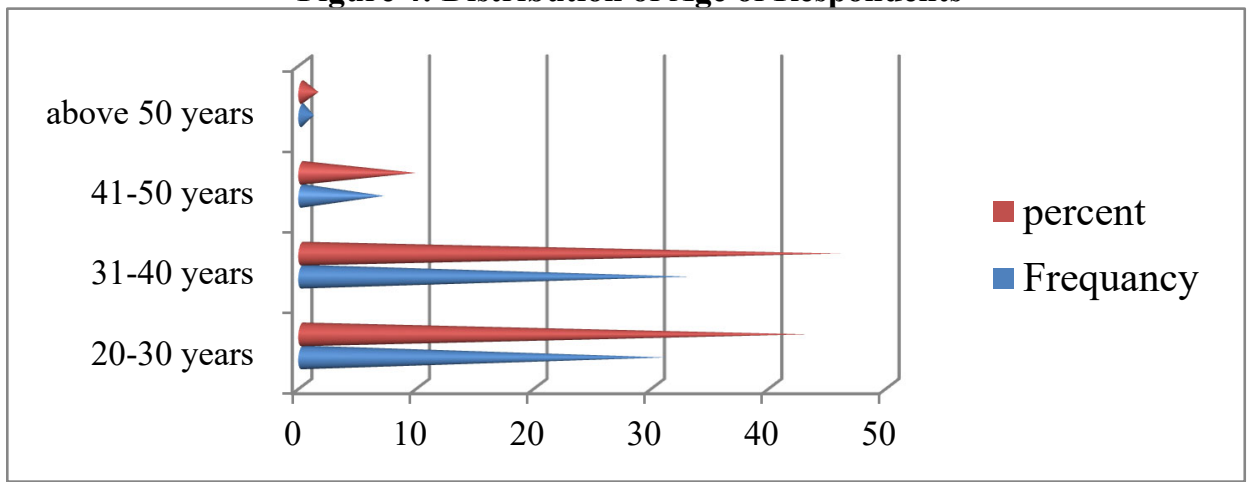

Source: own computation from field Survey.

\section{Education level of the responents}

Figure 5 illustrated that educational qualification of respondents. The majority ( 59.7 perecent) of the respondents were degree holders while only one-third (33.3\%) of the respondents were master's degree holders.

\section{Figure 5: Distribution of Educational Qualification of Respondents}

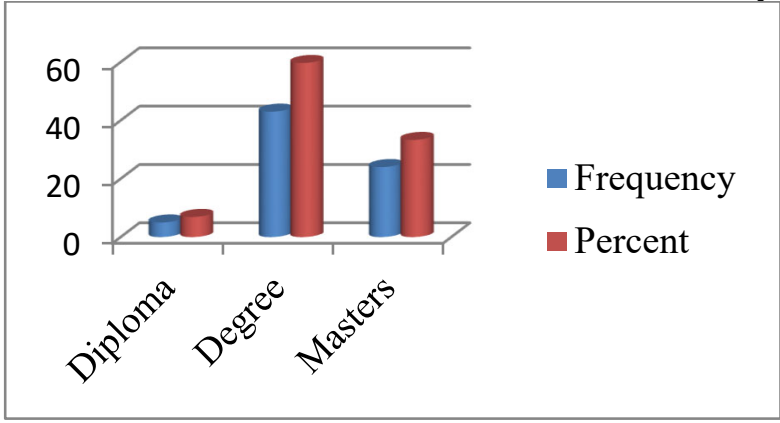

Source: own computation from field Survey

Service year of respondents

as depicted in figure 6 , fifty-three percent of the respondents have 6-10 years of work experience whil enearly onefourth (21 percent) of the respondents have $0-5$ years of work experience.

Figure 6: Distribution of Service Year of Respondents

\begin{tabular}{|c|c|c|c|c|c|}
\hline & \multicolumn{5}{|c|}{53} \\
\hline & $=71$ & & -15 & 4 & 7 \\
\hline & $0_{5 \text { years }}^{0}$ up to & $\begin{array}{c}6 \text { up to } 10 \\
\text { years }\end{array}$ & $\begin{array}{c}11 \text { up to } 15 \\
\text { years }\end{array}$ & $\begin{array}{l}16 \text { up to } \\
20 \text { years }\end{array}$ & $\begin{array}{c}21 \text { and } \\
\text { above } \\
\text { years }\end{array}$ \\
\hline Frequency & 14 & 36 & 10 & 3 & 5 \\
\hline Percent & 21 & 53 & 15 & 4 & 7 \\
\hline
\end{tabular}

Source: own computation from field Survey

\section{Training and Development}

Table 1 showed that respondents report on training and development practice in the context of Polices, directives and resources. The first statement was about whether the institute has defined training and development policy or not. Regarding to this statement $36(50 \%)$ of the respondents said agreed while 20 (27.87) of the respondents said disagreed. From this information, it is possible to conclude that the institute has defined training and development policy.

The second statement was about whether the institute has designed training and development system with directives or not. Regarding to this statement, $41(50.1 \%)$ of the respondents stated thatthey agreed with this statement while $16(22.2 \%)$ of the respondents were neutral to this statement. Thus from this information, it is possible to say that the institute has designed training and development system with directives.

The third statement was about training and development practices are conducted based on rule and regulation. Concerning this, $27(37.5 \%)$ of the respondents said agreed while $25(34,7 \%)$ of the respondents said disagreed. 
Hence, it is fairly possible to see that training and development practices are conducted based on rules and regulations.

The fourth statement was about training and development policies and program are integrated into the objectives of the organization. In this regards $34(47.3 \%)$ of the respondents indicated that they agreed with the ststement while $21(29.2 \%)$ of the respondents disagreed. From this, it can possible to say that training and development policies and program are integrated into the objective of the organization.

The sixth statement was about whether there is series attention to allocate sufficient budget and resources for the training and development. Against this statement about $23(32.0 \%)$ of the respondents replied that they agreed while $27(37.5 \%)$ of the respondents replied disagreed with this particular statement. It also possible to conclude that there is no series of attention to allocate sufficient budget and resource for the training and development in institution.

The seventh statement was about wheter there is series attention in the allotment of time for the training and development. In this regards, about $33.4 \%$ of the respondents agreed while $37.5 \%$ of the respondents disagreed with this ststement. This implies that there is no series of attention of allotment of time training and development. Moreover, the interview reported that

The institute has no defined training policy. Training and development are conducted in accordance with directives and training and development committee. Under human resource department has the responsibility to monitor and follow up the training and development training and development team assigned in accordance with the institutional structure.

The other reported that

We have developed guidelines (directives) and manuals based on the Federal public service commission document. The Modification was made by considering the organization context. The policy of human resource development is under ratification at the federal level. Then the organization has no policy of training and development.

Regarding the availability of resource the interviewee reported that

There is no shortage of budget and resource for training and development but the problem is the proper utilization of allotted budget and fulfilling the training facilities. Moreover, there is a problem with procurement. Some professional training need outdoor trainer but sometimes the institute get difficulty training center which fulfills the training demand of the ETDI.

Table 1: Respondents report on Training and development practice in the context of Polices, directives and resources

\begin{tabular}{|c|c|c|c|c|c|c|c|c|c|c|c|}
\hline \multirow[t]{2}{*}{ No } & \multirow[t]{2}{*}{ Statements } & \multicolumn{2}{|l|}{ SD } & \multicolumn{2}{|l|}{$\mathrm{D}$} & \multicolumn{2}{|l|}{$\mathrm{N}$} & \multicolumn{2}{|l|}{$\mathrm{A}$} & \multicolumn{2}{|c|}{ SA } \\
\hline & & है & $\frac{\sqrt{3}}{3}$ & $\frac{3}{0}$ & $\frac{3}{3}$ & $\frac{3}{3}$ & 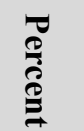 & $\frac{3}{3}$ & $\frac{\sqrt{0}}{\stackrel{0}{0}}$ & $\frac{7}{8}$ & $\frac{\mathfrak{3}}{3}$ \\
\hline 1 & $\begin{array}{l}\text { The Institute has defined training and } \\
\text { development policy }\end{array}$ & 7 & 9.7 & 13 & 18.1 & 16 & 22.2 & 29 & 40.3 & 7 & 9.73 \\
\hline 2 & $\begin{array}{l}\text { The Institute has designed training } \\
\text { and development system with } \\
\text { directives }\end{array}$ & 2 & 2.8 & 13 & 18.1 & 16 & 22.2 & 33 & 45.8 & 8 & 11.1 \\
\hline 3 & $\begin{array}{l}\text { Training and development practices are } \\
\text { conducted based on rule and regulation }\end{array}$ & 6 & 8.3 & 19 & 26.4 & 20 & 27.8 & 20 & 27.8 & 7 & 9.72 \\
\hline 4 & $\begin{array}{l}\text { Training and development Policies and } \\
\text { programs are integrated to the } \\
\text { objectives of the organization }\end{array}$ & 4 & 5.6 & 12 & 16.7 & 21 & 29.2 & 31 & 43.1 & 3 & 4.22 \\
\hline 5 & $\begin{array}{l}\text { Training and development programs } \\
\text { are designed based on need assessments }\end{array}$ & 4 & 5.6 & 19 & 26.4 & 20 & 27.8 & 23 & 31.9 & 6 & 8.3 \\
\hline 6 & $\begin{array}{l}\text { There is serious attention to allocate } \\
\text { sufficient budget and resource for the } \\
\text { training and development }\end{array}$ & 9 & 12.5 & 18 & 25 & 22 & 30.6 & 19 & 26.4 & 4 & 5.6 \\
\hline 7 & $\begin{array}{l}\text { There is serious attention in the } \\
\text { allotment of time for the training and } \\
\text { development }\end{array}$ & 9 & 12.5 & 18 & 25 & 21 & 29.2 & 21 & 29.2 & 3 & 4.2 \\
\hline
\end{tabular}

Source: own computation from field Survey

Training and Development Needs Assessment

Table 2 deals with respondents report on training and development needs assessment. To describe the training and 
development statements were designed and the result summarized as follows.

Statement 1: In ETIDI there is SMART manual and instrument of need assessment. In this regards, more than one in four $(29.2 \%)$ of the respondents disagreed with this statement while about one in three $(33.3 \%)$ of the respondents were neutral about the statement. This implies that in ETIDI there is no SMART manual and instrument of need assessment. Statement 2: The need assessment checklist filled without any bias and genuine. In this regards, $27(37.5 \%)$ of the respondents were neutral to the statement while $25(31.9 \%)$ of the respondents disagreed. This implies that respondents have neutral response to the need assessment checklist filed without bias and genuine.

Statement 3: Training and development need assessment manual is prepared by considering the need of prospective trainers. Concerning to this, 26(36.1\%) of the respondents said disagreed while $24(33.3 \%)$ of the respondents said agreed. This implies that training and development need assessment is not prepared by considering the need for prospective trainees. Statement 4: In the organization need of training and development are properly prioritized by considering the interest of prospective employee who is going to train. In this regards, $28(38.9 \%)$ of the respondents reported disagreed while $24(33.4 \%)$ of the respondents said agreed. From the above information, it is possible to conclude that in the organization need of training and development are not properly prioritized by considering the interest of prospective employee who is going to train. Statement 5: The training and development need analysis methods enable to clearly identify in relation to employees need to perform their jobs. In this regards $28(38.9 \%)$ of the respondents were neutral while $23(33.3 \%)$ of the respondents were agreed. From the above information, it is possible to conclude that respondents were neutral to the training and development need analysis methods enable to clearly identify in relation to employees need to perform their jobs. Statement 6: ETIDI training and development is practiced based on the work needs. In this regards $28(38.9 \%)$ of the respondents were disagreed, $28(36.1 \%)$ of the respondents were agreed. From the above information, it is possible to conclude that ETIDI training and development is not practical by based on the work needs. Statement 7: Training and development need analysis conducted is able to produce relevant finding on the performance jobs. In this regards, $29(40.3 \%)$ of the responds were neutral to the statement while $23(31.0 \%)$ of the respondents said agreed from the above information it is possible to conclude that respondents were neutrals to training and development need analysis conducted able to produce relevant finding on the performance jobs. Statement 8: The organized training by the institute is for the sake of refreshment or to collect allowance with less attention to the outcome of training. In this regards, $28(38.9 \%)$ of the respondents said disagreed while $23(32.0 \%)$ of the respondents said agreed. From the above information, it is possible to conclude that the organized training by the Institute is not for the sake of refreshment or to collect allowance with less attention to the outcome of the training. In addition to this, the interviewee report that

..... Need assessment is conducted. Need assessment practices of the institute is supported by PEST and SWOT analysis. The officers make decision on training and development based on what the employee suggested. Because of this, some trainings are not fit with the Institute objectives. The employee may suggest training area for the sake of self-benefits and to make free from the office routine for sometimes and for refreshment. The officers still do not consider the interest or objectives of the Institute. So the employees do not integrate the training to the organization objectives. The training is mostly out of the objectives, it is considered as one means to collect allowance. Thus, training need assessment conducted in the organization and the training organized do not fit with the organizational objectives.

Other interviewee replied that

The training need is assessed under the human resource development team. The team assesses the need for training and development by standardized format. The workers filled checklist of three training needs and approved by the immediate boss. Then, it is sent to the screening team of HRM. The human resource department includes in its planning. 
Table 2: Respondents report on Training and Development Needs Assessment

\begin{tabular}{|c|c|c|c|c|c|c|c|c|c|c|c|}
\hline \multirow[b]{2}{*}{ No } & \multirow[b]{2}{*}{ Statements } & \multicolumn{2}{|c|}{ SD } & \multicolumn{2}{|l|}{ D } & \multicolumn{2}{|l|}{$\mathrm{N}$} & \multicolumn{2}{|l|}{ A } & \multicolumn{2}{|c|}{ SA } \\
\hline & & है & 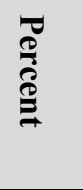 & 产 & 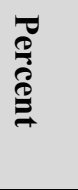 & 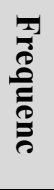 & 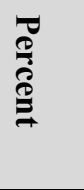 & 承 & 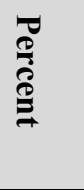 & 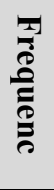 & 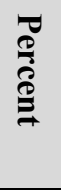 \\
\hline 1 & $\begin{array}{l}\text { In ETIDI there is SMART manual and } \\
\text { instrument of need assessment. }\end{array}$ & 10 & 13.9 & 21 & 29.2 & 24 & 33.3 & 14 & 19.4 & 3 & 4.2 \\
\hline 2 & $\begin{array}{l}\text { The need assessment checklist filled with } \\
\text { out bias and is genuine. }\end{array}$ & 5 & 6.9 & 18 & 25 & 27 & 37.5 & 19 & 26.4 & 3 & 4.2 \\
\hline 3 & $\begin{array}{l}\text { Training \& development need assessment } \\
\text { manual is prepared by considering the } \\
\text { need of prospective trainees. }\end{array}$ & 9 & 12.5 & 17 & 23.6 & 24 & 33.3 & 17 & 23.6 & 4 & 5.6 \\
\hline 4 & $\begin{array}{l}\text { In the organization need of training and } \\
\text { development are properly prioritized by } \\
\text { considering the interest of prospective } \\
\text { employee who is going to train. }\end{array}$ & 8 & 11.1 & 20 & 27.8 & 19 & 26.4 & 22 & 30.6 & 2 & 2.8 \\
\hline 5 & $\begin{array}{l}\text { The training and development need } \\
\text { analysis methods enable to clearly } \\
\text { identify in relation to employee need to } \\
\text { perform their job. }\end{array}$ & 5 & 6.9 & 15 & 20.8 & 28 & 38.9 & 19 & 26.4 & 5 & 6.9 \\
\hline 6 & $\begin{array}{l}\text { ETIDI training and development is } \\
\text { practiced based on your work needs. }\end{array}$ & 8 & 11.1 & 20 & 27.8 & 18 & 25 & 20 & 27.8 & 6 & 8.3 \\
\hline 7 & $\begin{array}{l}\text { Training and development need analysis } \\
\text { conducted is able to produce relevant } \\
\text { findings on performance gaps. }\end{array}$ & 3 & 42 & 17 & 23.6 & 29 & 40.3 & 19 & 26.4 & 4 & 5.6 \\
\hline 8 & $\begin{array}{l}\text { The organized training by the institute is } \\
\text { for the sake of refreshment or to collect } \\
\text { allowance with less attention to the } \\
\text { outcome of training. }\end{array}$ & 7 & 9.7 & 21 & 29.2 & 21 & 29.2 & 20 & 27.8 & 3 & 4.2 \\
\hline
\end{tabular}

Source: own computation from field Survey

Training and Development Plans, Objectives and Roles

Table 3 showed that respondents report on training and development plans, objective and roles. To describe training and development plans, objectives and roles statements were designed and the result from field survey presented or summarized as follows. Statement 1: training and development objectives are set in advance. Against this statement $34(47.3 \%)$ of the respondents reported agreement to the statement while $17(23.7 \%)$ of the respondents disagreed to the statement. From the above information, it is possible to say training and development objectives are not set in advance. Statement 2: the organization in its program has set SMART training and development objectives in this regards, 26(36.1\%) of the respondents said agreed while $27(37.5 \%)$ of the respondents said disagreed. From the above information, it is possible to say that the organization in its progress has set SMART training and development objectives.

Statement 3: the organization's training and development plan havvveee been developed in accordance with the strategic plan. Against this statement 26(36.1\%) of the respondents said agreed while $26(36.1 \%)$ of the respondents were neutral to the statement. From the above information, it is possible to say that the organizations training and development plan has been developed in accordance with the strategic plan. Statement 4: The organization training and development plan preparation allows the participation of all employees. In this regards, 30(41.7\%) of the respondents said disagreed while 24(33.33.4\%) of the respondents said agreed. From the above information, it is possible to conclude that the organization training and development plan preparation do not allow the participation of all employees. Statement 5: The training and development plan of the organization is well communicated to all partners and stakeholders. Against this statement, 29(40.3\%) of the respondents were disagreed while $22(30.6 \%)$ of the respondents were neutral to the statement. From the above information, it is possible to conclude that the training and development plan of the organization and not well communicated to all partners and stakeholders.

Statement 6: The training and development program of the organization is designed compatible with the actual job to be performed. Against this statement 28(37.9\%) of the respondents were disagreed while 27(37.5\%) of the respondent were agreed. From the above information, it is possible to conclude that training and development 
program of the organization is not designed compatible with the actual job to be performed.

Statement 7: The organization reviews its strategies and objective to have feedback for training and development for future possible arrangements. In this regards, 31(44.5\%) of the respondents replied agreed while 24(30.6\%) of the respondents replied disagreed. From the above information, it is possible to summarize the aspect as the organization reviews of its strategies and objectives to have feedback for training and development for future possible arrangements. Statement 8: Training and development programs allow acquiring skills, knowledge, and attitude improves employee's performance. Against this statement 50(69.4\%) of the respondents were agreed while $14(19.4 \%)$ of the respondents were neutral to the statement. From the above information, it is possible to conclude that training and development program allow acquiring skills, knowledge, and attitude to improve employee's performance. Statement 9: Training and development consider the employee's future career development. Against this statement, $39(54.2 \%)$ of the respondents were agreed while $19(26.3 \%)$ of the respondents were disagreed. From the above information, it is possible to conclude that training and development do consider the employee's future career development. The interviewee report that based on need assessment training and development plan is being prepared and the objectives were set in the plan.

Table 3: Respondents report on Training and Development Plans, Objectives and Roles

\begin{tabular}{|c|c|c|c|c|c|c|c|c|c|c|c|}
\hline \multirow[b]{2}{*}{$\begin{array}{c}\mathrm{N} \\
\mathrm{O}\end{array}$} & \multirow[b]{2}{*}{ Statements } & \multicolumn{2}{|l|}{$\mathrm{SD}$} & \multicolumn{2}{|l|}{$\mathrm{D}$} & \multicolumn{2}{|l|}{$\mathrm{N}$} & \multicolumn{2}{|l|}{ A } & \multicolumn{2}{|l|}{ SA } \\
\hline & & $\frac{3}{3}$ & $\frac{\overparen{a}}{\stackrel{9}{0}}$ & $\frac{1}{3}$ & 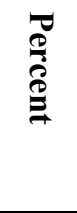 & $\frac{3}{3}$ & 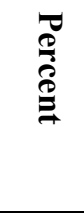 & $\frac{3}{3}$ & 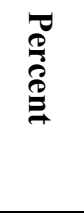 & $\frac{3}{3}$ & $\stackrel{0}{\overparen{0}}$ \\
\hline 1 & $\begin{array}{l}\text { Training and development } \\
\text { objectives are set in advance }\end{array}$ & 4 & 5.6 & 13 & 18.1 & 21 & 29.2 & 31 & 43.1 & 3 & 4.2 \\
\hline 2 & $\begin{array}{l}\text { The organization in its programs has } \\
\text { set SMART training and } \\
\text { development objectives. }\end{array}$ & 5 & 6.9 & 14 & 19.4 & 27 & 37.5 & 23 & 31.9 & 3 & 4.2 \\
\hline 3 & $\begin{array}{l}\text { The organization's training and } \\
\text { development plan has been } \\
\text { developed in accordance with the } \\
\text { strategic plan }\end{array}$ & 2 & 2.8 & 18 & 25 & 26 & 36.1 & 23 & 31,9 & 3 & 4.2 \\
\hline 4 & $\begin{array}{l}\text { The organization training and } \\
\text { development plan Preparation } \\
\text { allows the participation of all } \\
\text { employees. }\end{array}$ & 8 & 11.1 & 22 & 30.6 & 18 & 25 & 20 & 27.8 & 4 & 5.6 \\
\hline 5 & $\begin{array}{l}\text { The Training and development plan } \\
\text { of the organization is well } \\
\text { communicated to all partners } \\
\text { \&stakeholder }\end{array}$ & 8 & 11.1 & 21 & 29.2 & 22 & 30.6 & 18 & 25 & 3 & 4.2 \\
\hline 6 & $\begin{array}{l}\text { Training and development program } \\
\text { of the organization is designed } \\
\text { compatible with the actual job to be } \\
\text { performed. }\end{array}$ & 7 & 9.7 & 21 & 29.2 & 17 & 23.6 & 25 & 34.7 & 2 & 2.8 \\
\hline 7 & $\begin{array}{l}\text { The organization reviews of its } \\
\text { strategies and objectives to have } \\
\text { feedback for training and } \\
\text { development for future possible }\end{array}$ & 4 & 5.6 & 18 & 25 & 18 & 25 & 29 & 40.3 & 3 & 4.2 \\
\hline 8 & $\begin{array}{l}\text { Training and development programs } \\
\text { allow acquiring skills, knowledge } \\
\text { and attitude improve employee's }\end{array}$ & 3 & 4.2 & 5 & 6.9 & 14 & 19.4 & 44 & 61.1 & 6 & 8.3 \\
\hline 9 & $\begin{array}{l}\text { Training \& development considers } \\
\text { the employee's future career } \\
\text { development. }\end{array}$ & 5 & 6.9 & 14 & 19.4 & 14 & 19.4 & 35 & 48.6 & 4 & 5.6 \\
\hline
\end{tabular}

Source: own computation from field Survey

Methods of Training Delivery \& Development Practice

Table 4 showed that the method of training delivery and development practice. To assessment method of delivery 
and development practice statements were designed which can describe the situation and the result from field survey presented or summarized as follows. The first statement deals with whether the organization gives both on job and off-job training. In this regards, 45(63.5\%) of the respondents said agreed while 14(19.4\%) of the respondents said disagreed. Thus, from the above information, it is possible to conclude that the organization gives both on job and off job training. The second statement depicted that the delivery method that the organization employed is proper to acquire the necessary knowledge skills and attitudes in this regards, 34(47.2\%) of the respondents said agree while $20(27.8 \%)$ of the respondents said neutral. Thus, the delivery method that the organization employed is proper to acquire the necessary knowledge, skills and attitudes.

The third statement is the organization is employed trainee-centered training and development delivery method. In this regards, 28 (38.9\%) of the respondents said agreed. Thus, from the above information, it is possible to say respondents were not quite sure whether the organization employed trainee centered training and development delivery method. The fourth statement was whether the trainer has knowledge, skill, and ability to transfer and demonstrate the content of training and development is appropriate. Regarding to this, 37(51.4\%)of the respondents said agree while, $20(27.8 \%)$ of the respondents were neutral. Thus, from the above information, it is possible to say that trainer has knowledge, skills and ability to transfer and demonstrate the content of training development appropriately. The fifth statement was in the training and development practice/program facilitates, equipment and training aids is provided in accordance with the level of trainees. In this regards, 31(33.0\%) of the respondents said agreed while $22(30.6 \%)$ of the respondents said disagreed. This implies that the training and development practical program facilities, equipment and training aide and provided in accordance with the level of trainees.

The sixth statements were there is safe and conducive environment to conduct training and development in the institute. Regarding to this, $28(38.7 \%)$ of the respondents said agree while $24(33.8 \%)$ of the respondents said disagreed. Thus, there is safe and conducive environment to conduct training and development in the institute.

The seventh statement was training and development conducted is fit to intended purposes and objectives with the method employed. Regarding to, this issue, $32(34.5 \%)$ of the respondents said agree while $25(34.7 \%)$ of the respondents said neutral. This implies that training and development conducted is fit to the intended purpose and objectives with the method employed. The Eighth statements were the training conducted in collaboration with other country to share the best experience. In this regards, 35(48.6\%) of the respondents said agree while $19(26.4 \%)$ of the respondents said disagreed. This implies that the training conducted in collaboration with the country helps to share the best experience

Interview were reported that

The method of training used most of the time were lecture and demonstration. The Tnstitute organizes off training and on job training. The training was conducted off training in collaboration with Ethiopian management Institute, chamber commerce, Ethiopian civil service University, Ethiopian civil aviation academy.

The other interviewee reported that

With regards to the country need to agro-industry development, textile manufacturing is prior sector in response to this development a lot of textile industries developed by investment. The institute missions also build the capacity of human resource of the industries. The only institute which can accomplish the capacity building mission in our country. So the institute has vanguard task to empower human resource in this sector. Due to this, the Institute sends the experts to the three India's Textile technology institutes namely, NIFI - National institution of Technology, IIT- Indian Institute of Technology and ICT - Institute of Chemical Technology for education, traning and experiance sharing. The traing is conducted by twining program. In addition to this, in collaboration with Ethiopian Universities and Ethio-China Technical, Vocational and Training College, the institute organizes trainings. The institute also organizes shortterm training in collaboration with management institute, Ethiopian aviation academy and chamber of commerce. The training mode of delivery is off job training and on Job training. 
Table 4: Respondents report on Methods of Training Delivery \& Development Practice

\begin{tabular}{|c|c|c|c|c|c|c|c|c|c|c|c|}
\hline \multirow[b]{2}{*}{ No } & \multirow[b]{2}{*}{ Statements } & \multicolumn{2}{|c|}{ SD } & \multicolumn{2}{|l|}{$\mathrm{D}$} & \multicolumn{2}{|l|}{$\mathrm{N}$} & \multicolumn{2}{|l|}{ A } & \multicolumn{2}{|c|}{ SA } \\
\hline & & 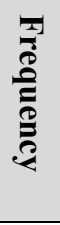 & $\begin{array}{l}\frac{2}{3} \\
\stackrel{0}{0}\end{array}$ & $\begin{array}{l}3 \\
\frac{3}{8} \\
\frac{3}{0} \\
\stackrel{3}{3}\end{array}$ & 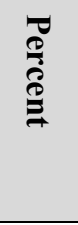 & 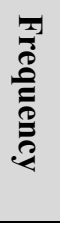 & 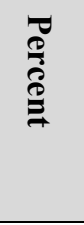 & $\frac{\overrightarrow{8}}{8}$ & 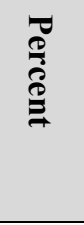 & $\frac{3}{3}$ & 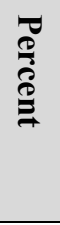 \\
\hline 1 & $\begin{array}{l}\text { The organization gives both on-job and off- } \\
\text { job training }\end{array}$ & 5 & 6.9 & 9 & 12.5 & 13 & 18.1 & 38 & 52.8 & 7 & 9.7 \\
\hline 2 & $\begin{array}{l}\text { The delivery method that the organization } \\
\text { employed is proper to acquire the } \\
\text { necessary knowledge, skills and attitudes }\end{array}$ & 3 & 4.2 & 15 & 20.8 & 20 & 27.8 & 33 & 45.8 & 1 & 1.4 \\
\hline 4 & $\begin{array}{l}\text { The organization is employed trainee- } \\
\text { centered training and development } \\
\text { delivery method }\end{array}$ & 3 & 4.2 & 14 & 19.4 & 28 & 38.9 & 25 & 34.7 & 2 & 2.8 \\
\hline 5 & $\begin{array}{l}\text { The trainers have knowledge, skills and } \\
\text { ability to transfer and demonstrate the } \\
\text { content of training and development } \\
\text { appropriately }\end{array}$ & 3 & 4.2 & 11 & 15.3 & 20 & 27.8 & 33 & 45.8 & 4 & 5.6 \\
\hline 6 & $\begin{array}{l}\text { In the training and development practice } \\
\text { /program facilities, equipment's and } \\
\text { training aids is provided in accordance with } \\
\text { the level of trainees. }\end{array}$ & 2 & 2.8 & 20 & 27.8 & 18 & 25 & 26 & 56.1 & 5 & 6.9 \\
\hline 7 & $\begin{array}{l}\text { There is safe and conducive environment to } \\
\text { conduct training and development in the } \\
\text { institute }\end{array}$ & 4 & 5.6 & 20 & 27.8 & 20 & 27.8 & 23 & 31.9 & 5 & 6.9 \\
\hline 8 & $\begin{array}{l}\text { Training and development conducted is fit } \\
\text { to intended purposes and objectives with } \\
\text { the method employed }\end{array}$ & 4 & 5.6 & 11 & 15.3 & 25 & 34.7 & 28 & 38.9 & 4 & 5.6 \\
\hline 9 & $\begin{array}{l}\text { The training Conducted in collaboration } \\
\text { with other country to share best experience. }\end{array}$ & 6 & 8.3 & 13 & 18.1 & 18 & 25 & 32 & 44.4 & 3 & 4.2 \\
\hline
\end{tabular}

Source: own computation from field Survey

\section{Training and Development Evaluation}

Table 5 showed that respondents report on training and development evaluation. To describe this idea statements were desisted and presented as follows;

Statement 1: The organization evaluates the training and development practice before, on the process and after the program. In this regard, 34(47.3\%) of the respondent said disagreed while 20(27.8\%) of the respondent said agreed. This implies that the organization does not evaluate, the training and development practice before, one process and after the program. Statement 2: The organization use feedback at the ends of the training and development program. In this regards, $34(61.1 \%)$ of the respondent said agreed while $14(19.4 \%)$ of the respondents were neutral to the issue. From the above information, it is possible to conclude that the organization uses feedback at the end of the training and development program. Statement 3: Training evaluation used to identify potential candidate for current training and future development concerning to this, $27(40.3 \%)$ of the respondents said agreed while 24(33.3\%) of the respondent it is possible to conclude that training and evaluation used to identify Potential candidate for current training and future development. Statement 4: Training and evaluation assess the gap before and after the delivery of the training. Regarding to this issue, 31(33.1\%) of the respondents said agreed while $23(32 \%)$ of the respondent said disagreed. This implies that training and evaluation assess the gap before and after delivery of the training. Statement 5: The management makes feedback to fill the gap and improve the effectiveness of training and development. In this regards $30(41.6 \%)$ of the respondents said disagreed while $21(29.2 \%$ ) of the respondents said agreed. It is possible to conclude that the management does not make feedback to fill the gap and improve the effectiveness of training and development.

Interviewee reported that

The training is bias-free, the misuse allocated time, the problems of identifying the gap of employee and the organization training need. Moreover, there is weak perception about the training and not giving due attention to the benefits of training. There is no auditing what is achieved from the training. 
Table 5: Respondents Report on Training and Development Evaluation

\begin{tabular}{|c|c|c|c|c|c|c|c|c|c|c|c|}
\hline \multirow[b]{2}{*}{ No } & \multirow[b]{2}{*}{ Statements } & \multicolumn{2}{|l|}{ SD } & \multicolumn{2}{|l|}{ D } & \multicolumn{2}{|l|}{$\mathbf{N}$} & \multicolumn{2}{|c|}{$\mathbf{A}$} & \multicolumn{2}{|l|}{ SA } \\
\hline & & $\frac{3}{3}$ & 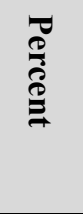 & 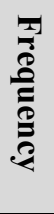 & 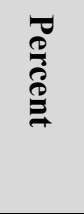 & 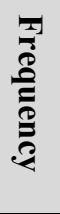 & 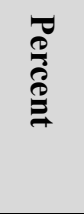 & 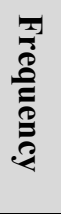 & $\frac{\overparen{2}}{2}$ & 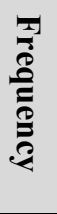 & $\frac{0}{3}$ \\
\hline 1 & $\begin{array}{l}\text { The organization evaluates the training } \\
\text { and development practice before, on } \\
\text { process and after the program. }\end{array}$ & 12 & 16.7 & 22 & 30.6 & 18 & 25 & 19 & 26.4 & 1 & 1.4 \\
\hline 2 & $\begin{array}{l}\text { The organization use feedback at the end } \\
\text { of the training and development program. }\end{array}$ & 5 & 6.9 & 8 & 11.1 & 14 & 19.4 & 38 & 52.8 & 6 & 8.3 \\
\hline 3 & $\begin{array}{l}\text { Training evaluation used to identify } \\
\text { potential candidate for current training \& } \\
\text { future development. }\end{array}$ & 4 & 5.6 & 15 & 20.8 & 24 & 33.3 & 22 & 30.6 & 7 & 9.7 \\
\hline 4 & $\begin{array}{l}\text { Training evaluation assesses the gap } \\
\text { before and after delivery of the training. }\end{array}$ & 4 & 5.6 & 19 & 26.4 & 18 & 25 & 27 & 37.5 & 4 & 5.6 \\
\hline 5 & $\begin{array}{l}\text { The management makes feedback to fill } \\
\text { the gap \& improve the effectiveness of the } \\
\text { training\& development. }\end{array}$ & 6 & 8.3 & 24 & 33.3 & 21 & 29.2 & 18 & 25 & 3 & 4.2 \\
\hline
\end{tabular}

Source: own computation from field Survey

\section{Problems/challenges of Training and Development}

Table 6 showed that respondents report on problem challenges of training and development. In this regards, statements were designed as follows.

Statement1. Lack of necessary knowledge and skill on the part of the trainer. In this regards, $27(37.5 \%)$ of the respondents said disagreed while $23(32.0 \%)$ of the respondents said agreed from the above information it is possible to conclude that there is no lack of necessary knowledge and skill on the part of the training. Statement 2: Unclear training and development performance. In this regards, 26(36.2\%) of the respondents said agreed while $24(33.4 \%)$ of the respondents said disagreed, this implies that there are unclear training and development performance.

Statement 3: Poor administration of training and development performance process. In this regards, 37(41.4\%) of the respondent said agreed while $17(23.6 \%)$ of the respondent disagreed. From the above information, it is possible to conclude that there is poor administration of training and development program process. Statement 4: The purpose of training and development perform being in realistic. Concerning to this $25(34.7 \%)$ of the respondents were related to the statement while $23(31.9 \%)$ of the respondent said agreed .From the above information, it is possible to conclude that respondents were neutral to the purpose of the training and development process being unrealistic. Statement 5: Good training and development program not followed by rewards. In this regards, 44(61.1\%) of the respondents said agreed while 15(20.9\%) of the respondents said disagreed. From the above information, it is possible to say good training and development program do not followed by reward.

Statement 6:the training and development program are not related to the need of the organization, concerning to this $32(44.7 \%)$ of the respondent said disagreed while $21(29.2 \%)$ of the respondents said agreed. From the above information, it is possible to conclude that the training and development program are related to the need of the organization. Statement 7: Lack of timely feedback with regard to trainee's satisfaction. In this regard 24(37.5\%) of the respondent said disagreed. From the above information, it is possible to say there is lack of timely feedback with regard to trainees satisfaction. Statement 8: Lack of resource and budget in this regards, 33(48.5\%) of the respondents said disagreed while $24(33.4 \%)$ of the respondent said agreed. This implies that there is no lack of resources and budget. Statement 9: Time limitation on the part of trainers. In this regard, 28(38.9) of the respondents said disagreed while $23(32.0 \%)$ of the respondents said agreed. This implies that there is no time limitation on the part of trainers. 
Table 6: Respondents report on Problems/challenges of Training and Development

\begin{tabular}{|c|c|c|c|c|c|c|c|c|c|c|c|}
\hline \multirow[b]{2}{*}{ No } & \multirow[b]{2}{*}{ Statements } & \multicolumn{2}{|c|}{ SD } & \multicolumn{2}{|l|}{$\mathrm{D}$} & \multicolumn{2}{|l|}{$\mathrm{N}$} & \multicolumn{2}{|l|}{ A } & \multicolumn{2}{|l|}{ SA } \\
\hline & & $\begin{array}{l}3 \\
\frac{7}{8} \\
\frac{8}{3} \\
3 \\
3\end{array}$ & 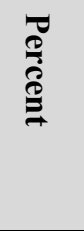 & 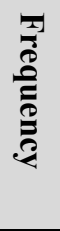 & $\frac{1}{3}$ & 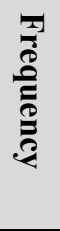 & $\frac{\text { 20 }}{3}$ & 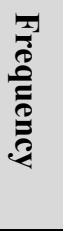 & 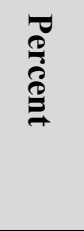 & 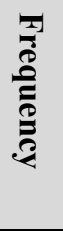 & $\frac{\sqrt{0}}{0}$ \\
\hline 1 & $\begin{array}{l}\text { Lack of necessary knowledge and skill } \\
\text { on the part of the trainer }\end{array}$ & 7 & 9.7 & 20 & 27.8 & 21 & 29.2 & 21 & 29.2 & 2 & 2.8 \\
\hline 2 & $\begin{array}{l}\text { Unclear training and development } \\
\text { program }\end{array}$ & 2 & 2.8 & 22 & 30.6 & 22 & 30.6 & 22 & 30.6 & 4 & 5.6 \\
\hline 3 & $\begin{array}{l}\text { Poor administration of the training and } \\
\text { development program process }\end{array}$ & 3 & 4.2 & 14 & 19.4 & 17 & 23.6 & 29 & 40.3 & 8 & 11.1 \\
\hline 4 & $\begin{array}{l}\text { The purpose the training and } \\
\text { development program being } \\
\text { unrealistic }\end{array}$ & 2 & 2.8 & 20 & 27.8 & 25 & 34.7 & 18 & 25 & 5 & 6.9 \\
\hline 5 & $\begin{array}{l}\text { Good training and development } \\
\text { program not followed by rewards }\end{array}$ & 3 & 4.2 & 12 & 16.7 & 12 & 16.7 & 36 & 50 & 8 & 11.1 \\
\hline 6 & $\begin{array}{l}\text { The training and development } \\
\text { programs are not related to the need of } \\
\text { the organization }\end{array}$ & 7 & 9.7 & 25 & 34.7 & 18 & 25 & 18 & 25 & 3 & 4.2 \\
\hline 7 & $\begin{array}{l}\text { Lack of timely feedback with regard } \\
\text { to trainees satisfaction }\end{array}$ & 4 & 5.6 & 18 & 25 & 23 & 31.9 & 21 & 33.3 & 3 & 4.2 \\
\hline 8 & Lack of resource and budget & 8 & 11.1 & 25 & 34.7 & 15 & 20.8 & 20 & 27.8 & 4 & 5.6 \\
\hline 9 & Time limitation on the part of trainers & 8 & 11.1 & 20 & 27.8 & 18 & 25 & 19 & 26.4 & 4 & 5.6 \\
\hline
\end{tabular}

Source: own computation from field Survey

\section{Correlation Analysis}

Correlation analysis with Pearson's correlation coefficient (r) was conducted on all variables in this study to explore the relationships between them. To interpret the strengths of relationships between variables, the guidelines suggested by Taylor R, (1990), was followed. If the correlation efficient (r) is less than 0.35 it considered to represent low or weak correlation; if the correlation efficient lies between 0.36 and 0.67 it considered modest or moderate correlation; if it lies beteewn 0.68 and 0.89 is strong or high correlation and a correlation with $r$ coefficient $\geq 0.90$ conidered to be a very high correlation. Again if the correlation result lies between -1 and 0 , the two variables are negatively related. Having this in mind, the result is interpreted and discussed using this criterion in each dimension. The result presented as follows.

According to table 7, the relationship between the depenent variable(training and development practices and challenges) and independent variable (training and development practices of polices, directives and resources) is found to be weak $(r=0.015)$ and a positive significant relationship. Likewise, training and development need assessment is positively correlated with dependent variable and the relationship between variables is significant(p $<0.05)$ and strong $(\mathrm{r}=0.713)$. Furthermore, Training and development plans, objectives, and roles is positively correlated with dependent variable and have strong and statistically significant relationship $(\mathrm{r}=0.664, \mathrm{p}<0.05)$. the method of delivery and development practices are found to have a positive and significant relationship with the dependent variable. Finally, problems/challenges of training and development was found to have a negative and significant relationship with the dependent vaiable(training and development practices and Challenges). 
Table 7: Correlation Analysis

\begin{tabular}{|c|c|c|c|c|c|c|c|c|}
\hline & & $\begin{array}{l}\text { Practices } \\
\text { and } \\
\text { Challenges }\end{array}$ & $\begin{array}{l}\text { practices in the } \\
\text { context of } \\
\text { Polices, } \\
\text { directives and } \\
\text { resources }\end{array}$ & $\begin{array}{l}\text { Training } \\
\text { Needs } \\
\text { Assessment }\end{array}$ & $\begin{array}{l}\text { Plans, } \\
\text { Objectives } \\
\text { and Roles }\end{array}$ & $\begin{array}{ll}\text { Methods } \quad \& \\
\text { Delivery of } \\
\text { Training } \\
\text { Development }\end{array}$ & $\begin{array}{l}\text { Training and } \\
\text { Development } \\
\text { Evaluation }\end{array}$ & $\begin{array}{l}\text { Problems/ch } \\
\text { allenges of } \\
\text { Training and } \\
\text { development }\end{array}$ \\
\hline Practices and & $\begin{array}{l}\text { Pearson } \\
\text { Correlation }\end{array}$ & 1 & & & & & & \\
\hline & Sig. (2-tailed) & & & & & & & \\
\hline $\begin{array}{l}\text { practices in the } \\
\text { context of }\end{array}$ & $\begin{array}{l}\text { Pearson } \\
\text { Correlation }\end{array}$ & $0.567^{* *}$ & 1 & & & & & \\
\hline $\begin{array}{l}\text { Polices } \\
\text { directives and } \\
\text { resources }\end{array}$ & Sig. (2-tailed) & 0.000 & & & & & & \\
\hline Training Needs & $\begin{array}{l}\text { Pearson } \\
\text { Correlation }\end{array}$ & $0.713^{* *}$ & $0.662^{* *}$ & 1 & & & & \\
\hline & Sig. (2-tailed) & 0.000 & 0.000 & & & & & \\
\hline $\begin{array}{l}\text { Plans, } \\
\text { Objectives and }\end{array}$ & $\begin{array}{l}\text { Pearson } \\
\text { Correlation }\end{array}$ & $0.664^{* *}$ & $0.451^{* *}$ & $0.777^{* *}$ & 1 & & & \\
\hline Roles & Sig. (2-tailed) & 0.000 & 0.000 & 0.000 & & & & \\
\hline $\begin{array}{l}\text { Methods of } \\
\text { Training }\end{array}$ & $\begin{array}{l}\text { Pearson } \\
\text { Correlation }\end{array}$ & $0.650^{* *}$ & $0.521^{* *}$ & $0.602^{* *}$ & $0.710^{* *}$ & 1 & & \\
\hline $\begin{array}{l}\text { Delivery \& } \\
\text { Development } \\
\text { Practice }\end{array}$ & Sig. (2-tailed) & 0.000 & 0.000 & 0.000 & 0.000 & & & \\
\hline $\begin{array}{l}\text { Training and } \\
\text { Development }\end{array}$ & $\begin{array}{l}\text { Pearson } \\
\text { Correlation }\end{array}$ & $0.622^{* *}$ & $0.557^{* *}$ & $0.541^{* *}$ & $0.581^{* *}$ & $0.640^{* *}$ & 1 & \\
\hline Evaluation & Sig. (2-tailed) & 0.000 & 0.000 & 0.000 & 0.000 & 0.000 & & \\
\hline $\begin{array}{l}\text { Problems/chall } \\
\text { enges of }\end{array}$ & $\begin{array}{l}\text { Pearson } \\
\text { Correlation }\end{array}$ & $-0.276^{*}$ & $-0.456^{* *}$ & $-0.343^{* *}$ & $-0.382^{* *}$ & $-0.398^{* *}$ & $-0.423^{* *}$ & 1 \\
\hline $\begin{array}{l}\text { Training and } \\
\text { development }\end{array}$ & Sig. (2-tailed) & 0.009 & 0.000 & 0.003 & 0.001 & 0.001 & 0.000 & \\
\hline
\end{tabular}

**. Correlation is significant at the 0.01 level (2-tailed).

*. Correlation is significant at the 0.05 level (2-tailed).

\section{Regression Analysis}

The study sought to establish how the dimension of training and development would influence on employee performance using multiple linear regression analysis. The dimensions were: training and development practices of polices, directives and resources, training needs assessment, training and development plans, objectives and roles, methods of training delivery \& development practice, training and development evaluation and problems/challenges of training and development. The regression model was:

$$
Y=\beta_{0}+\beta_{1} X_{1}+\beta_{2} X_{2}+\beta_{3} X_{3}+\beta_{4} X_{4}+\beta_{5} X_{5}+\beta_{6} X_{6}+\varepsilon
$$

Whereby $Y$ is training and development practices, $\beta_{0}$ is regression constant, $\beta_{1}-\beta_{6}$ regression coefficients, $\mathrm{X}_{1}$ is training and development policies, directives, and resources $\mathrm{X}_{2}$ is training and development needs assessment, $\mathrm{X}_{3}$ is training and development plans, objectives and roles, $\mathrm{X}_{4}$ is methods of training delivery and development practice $\mathrm{X}_{5}$ is training and development evaluation, $\mathrm{X}_{6}$ is problems/ challenges training and development and $\varepsilon$ model's error term..

\section{Table 8: Model's Goodness of Fit Statistic}

\begin{tabular}{|l|l|l|l|l|}
\hline Model & R & R Square & Adjusted R Square & Std. Error of the Estimate \\
\hline 1 & 0.79 & 0.63 & 0.59 & 0.31 \\
\hline
\end{tabular}

Source: own computation from field Survey

According to table $8, \mathrm{R}$ square is 0.625 which shows that $62.5 \%$ of the variation in the dependent variable is being explained by independent variables. This depicts that the model accounts for $62.5 \%$ of the variations in influencing training and development practices while 37.5\% remains unexplained by the regression model.

\section{Table 9: Analysis of Variance (ANOVA)}

\begin{tabular}{|l|l|l|l|l|l|l|}
\hline \multicolumn{2}{|l|}{ Model } & Sum of Squares & Df & Mean Square & F & Sig. \\
\hline \multirow{4}{*}{1} & Regression & 10.408 & 6 & 1.735 & 18.057 & 0.000 \\
\cline { 2 - 8 } & Residual & 6.245 & 65 & .096 & & \\
\cline { 2 - 7 } & Total & 16.653 & 71 & & & \\
\hline
\end{tabular}

Source: own computation from field Survey

The ANOVA statistics presented in Table 9 was used to present the regression model significance. An Fsignificance value of at $\mathrm{df}(6,65)$ with $\mathrm{P}$ value $=0.00<0.05$ indicate that the final regression model was found to be statistically significant. Thus, there is strong relation between dependent and independent variable. 
Table 10: Regression Analysis

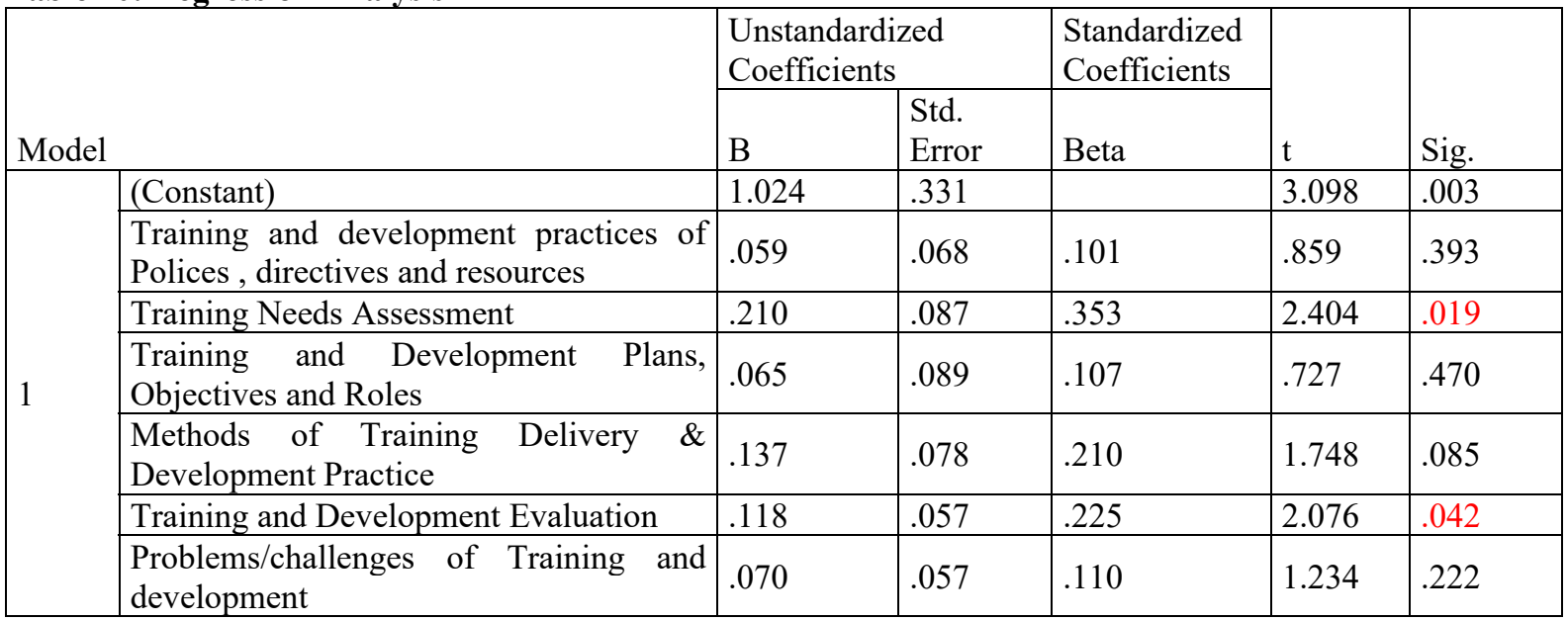

Source: own computation from field Survey

As we can see from table 10, only the two varibles namely, Training Needs Assessment and Training and Development Evaluation was found to be significant at 5\% level of significance. From the findings in Table 10 the multiple linear regression equation becomes:

$\mathrm{Y}=1.024+0.059 \mathrm{X}_{1}+0.210 \mathrm{X}_{2}+0.065 \mathrm{X}_{3}+0.137 \mathrm{X}_{4}+0.118 \mathrm{X}_{5}+0.070 \mathrm{X}_{6}$

Holding other factors constant, a unit increase in training and development practices of polices, directives and resources would lead to 0.059 increase in the practices and challenges of training and development. similarly a unit increase of training needs assessment would lead to 0.210 increase in the practices and challenges of training and development.

\section{Conclusions and Recommendations}

\section{Conclusions}

Based on the findings of the research the following conclusion were made

* The institute has defined training and development policy which can be explained by designed training and development system with directives;

* training and development practices are conducted based on rules and regulations;

* training and development policies and program are integrated into the objective of the organization;

* The organization use feedback at the end of the training and development program and the management doesn't make feedback to fill the gap and improve the effectiveness of training and development;

* training and development programs are designed based on need assessment;

* There is no series of attention to allocate time and sufficient budget and resource for the training and development;

* In ETIDI there is no SMART manual and instrument of need assessment and the need assessment checklist filed without bias and genuine;

* training and development need assessment is not prepared by considering the need of prospective trainees;

* The organized training by the Institute is for the sake of refreshment or to collect allowance with less attention to the outcome of the training;

* Training and development objectives are not set in advance;

* the organization training and development plan preparation do not allow the participation of all employees;

* training and development plan of the organization and not well communicated to all partners and stakeholders;

* training and development program of the organization is not designed compatible with the actual job to be performed;

* There is lack of necessary knowledge and skill on the part of the training;

* training and development program not followed by reward;

\section{Recommendations}

Based on the findings of the study, the following recommendations are forwarded:

- Management of the institute, the board and other stakeholders should define an appropriate training and development policy and programs bring or capacitate the organization as well as the employee.

- Management of the institute, the board and other stakeholders should clearly state the results of training and development before and after training is being conducted for each staff, what change in staff skill, attitude, 
behavior and knowledge. Management of Ethiopian Textile development institute should also clarify what is to change and to what extent training and development.

- Training objectives should be clear to both management of Ethiopian Textile development institute and staff because they can be used to assess the success of the institute as well as the employees.

- Staff in the institute should be helped to grow in to more responsibility by systematic training and development rather than consider it training as means to make themselves free from staff routine and receive allowance without considering the objective and benefits of training for themselves and for their institute so that they will be confident enough to carry out the responsibility of the job.

- Ethiopian Textile development institute should provide performance feedback which will allow staff to be informed of changes to both their work goals and the overall goals of the institute.

- Management of the institute, the board and other concerned bodies should come up with training and development practices and policies for their Ethiopian Textile development institute because they are the strategic link between the institute's vision and its day-to-day operations.

\section{Reference}

Abeeha B. and Bariha B.(2012). Effects of employee training on the origination a competitive advantage In private sector of Islamabad Pakistan, Far East Journal of psychology and business vol.16 no.Ip 63

Abenet Daresema. (2016).The Role of Decentralization in Education and Health Services Delivery in Addis Ababa City Government: Evidence from the Case of Yeka-Sub City; Addis Ababa University MA thesis

Amandi, JANE. (2014). The effect of training and development on employees' performance; at Safaricom limited call center. MA Thesis; University of Nairobi.

AmsaluTegegne. (2017). Assessing the Effect of Training and Development on Employees' Performance: A Case of Gulelle Sub-City Administration sectors; MA Thesis, Addis Ababa University.

AnasimosAlye.(2016).A Comparative Study Of Government And Private Banks- Training And Development Of Bank Employees; The Case Of Commercial Bank Of Ethiopian And Awash International Bank; MA Thesis, Addis Ababa University.

Anderson (2004), Training in Practice: Implementation of Plans, New Delhi: Cambridge.

Armstrong .M (2003).Human Resource Management practice 8th Edition London Koganpage Ltd.

Armstrong, M. (2006). A handbook of Human Resource Management (10th edition ed.). London \& Philadelphia: Kogan Page Limited.

Arthur, W. J., \& Bennett, W. J. (2003). Effectiveness of training in Organizations: A meta-analysis of design and evaluation features. Journal of applied Psychology, 234-245.

Assefa Gidey.(2016). The Effect of Training and Development on Employees Performance: the case of Commercial Bank of Ethiopian; MA Thesis, Addis Ababa University.

Attaran, M, \& Nguyen, T.T. (2000). Creating the right structure for self directed team. Team performance management, 6, 25-33.

Beardwell, I., Holden, L., \& Claydon, T. (2004). Human Resource Management: A contemporary approach, 4th Edition. London: Prentice- Hall.

BitewAmare.( 2016). Assessment of Employee Training and Development Policy, Practices and Problems: in the case of Africa Union Commission; MA Thesis, Addis Ababa University

Creswell T.W (2009).Research Design: Qualitative, Quantitative, and Mixed Methods Approach.( $\left.{ }^{\mathrm{rd}} \mathrm{ed}.\right)$, Cos Angeles SAGE Publications. Inf.

D. A. Olaniya, and Lucas. B. Ojo, (2008). Staff Training and development: A Vital Tool for Organizational Effectiveness (online). Available at http: //WWW.eurojournal. com/ ejsr. htm Accessed on 14/02/2019. European journal of Scientific Research. Vol.24 No. 3

Dacenzo and Robbins (2008). Training and development needs assessment: a practical model for partner institutes, Journal of European Industrial Training, Vol. 22/1, pp. 18-27.

Dacenzo, D. A., \& Robbins, S. P. (2010). Fundamentals of Human Resource Management (10th edition). Willey $\&$ Sons Inc

Eisen Berger R., Huntington, R. Hutchinson,S. and Sowa, D. (1986), 'Perceived organizational Support',Journal of Applied Psychology, vol.71,pp.500-507.

Esterby-Smith, M. (1986). Training course evaluation from an end to a means: Personnel Management.

Ethiopian Textile Development Institute (2017). Unpublished report document

Fletcher C Bradley C and Cunningham S. (1998). The psychometric properties of 360-degrees Feedback: an empirical study and cautionary tale; international journal of selection assessment vol, 6 .

Griffin, W. (2000).Principles and Practices of Management.9th ed. India. McGrrew Hill

H.O.FALALA. (2014). The effectiveness of Training \& Development. University of Brasov.

Hamid, S. (2011). Study of Effectiveness of Training \& Development. South Asian Journal of Tourism \& Heritage 
(2011), Vol.4,No.1.

Harrison, R. (2000). Employee Development, Beekman Publishing, Silver Lakes, Prectoria.

Holbeche, L. (2009). Aligning Human Resources and Business Strategy (2nd edition ed.). Elsevier Ltd.

Jackson, K., \& Rowley, C. (Eds.). (2011). Human Resource Mangement: The key concepts. New York: Routledge. Katcher, S., \& Snyder, T. (2003). Organizational Committment. USA: Atomic Dog.

Khan, F.A. and Khan,M.A. (2011). Impact of training and development on organizational performance. Global Journal of management and Business Research, 11, 2

Kirpatrick, D. L. (1994). Evaluating Training Programs: Evaluating training programs-the four levels. San Franscisco: Berrett- Koehler.

Kreitner, R., \& Kinicki, A. (2007). Organizational Behavior (7th ed.). New York: McGraw Hill/Irwin.

Learner, R(1986). Concepts and theories of Human Development (2nded.).New York Random House

Mamoria, C.B(1995).Personal management, Himalaya Publishing House New Delhi.

Mengestu Zeleke. (2014). The Practice And Problems Of Human Resource Development And Training At Vision Ethiopian Congress For Democracy Training Institution: MA Thesis, Addis Ababa University.

Nadler,L (1984). The handbook of Human Resource development (Glossary). New York: John Wiley \& Sons.

Noe, A.R. 2002. Employees Training and Development. New York: McGraw-Hill

Noe, R. (2001).Human Resource Management 2nd edition Prentice Hall.

Noe, R.A.,HollenBeck, J. R., Gerhart, B., \& Wright, P.M. (2008). Human Resource Management: Gaining a Competitive Advantage, 6th edition. New York: McGraw- Hill/Irwin.

PallaviP.k. (MS) Ulkran, (2013), literature review on training and development and quality of work life Journal of art, science and commerce, EISSN 2229-4686

Seligman L(1998). The relationship of facilitative functioning of effective peer supervision Counsellor education and supervision 17, $254-260$.

Steen, S. L., Noe, R. A., Hollenbeck, J. R., B. G., \& Write, P. M. (2009). Human Resource Management (Vol. 2nd Canadian edition). McGraw-Hill Ryerson Limited.

T. Hari Parkish, H. (2016). The effectiveness of Training and Development.

Valle, R., Martin, F., Romero, P. M., \& Dollan, S. (2000). Business strategy, work processes and human. Journal of Organizational Behavior, 21, 283-97. 